\title{
Carcass Characteristics of Saidi Rams Fed Mannan Oligosaccharide Supplemented Diet
}

Daghash, MW.H. ; M. N. Abd El-Ati ; F. M. Allam and S. F. Abbas

Department of Animal Production Faculty of Agriculture. Assiut University, Egypt.

\section{Abstract:}

Eighteen Saidi rams were used in this trial to study the impact of additive mannan oligosaccharide (MOS; activeMOS ${ }^{\circledR}$ )on some of carcass characteristics. MOS are commercially available as BioMos $\AA$, which is a nutritional supplement manufactured by $\operatorname{MOS}^{\circledR}$ Matrix nutrition, LLC, USA was used in this experiment. Animals were randomly divided into three equal groups. The initial average live body weight values were $24.00,24.08$ and $24.17 \mathrm{~kg}$ for groups 1,2 , and 3 respectively. The first group did not receive MOS and served as a control group, while the second and third groups were supplemented with 2 and $4 \mathrm{~g} / \mathrm{kg}$ diet MOS and served as a MOS ${ }^{1}$ and MOS $^{2}$ groups, respectively. Both experimental groups were fed roughage and concentrate diets ad libitum during this study. At the end of the experimental period, lasted for 6 months, final average body weight values were 44.17, 48.50 and 45.83, respectively. Five animals from experimental groups were slaughtered. The data revealed that supplementation of dietary MOS in the diet of siadi rams increased hot carcass weight, dressing percentage, right $(\mathrm{P}<0.05)$ and left side percentages. Moreover, most of edible and non edible parts tended to be heavier for MOS treated rams, while fat of heart, kidney and pelvic, gut, intestine and total fat tended to be lower for these groups than a control group. The proportion of muscle/ bone and muscle/fat ratios increased in treated groups. Left carcass side weight and carcass cuts were heavier in animals fed diet supplemented with MOS than controls. Meanwhile, a high priced cuts (leg, sirloin and best neck and fillet) were heavier by $29.05 \%$ and $12.7 \%$ of rams fed diet supplemented with $\operatorname{MOS}^{1}$ and $\mathrm{MOS}^{2}$ additives, respectively compared with the control. The highest part of high priced cuts was observed in fillet cut for $\mathrm{MOS}^{1}$ and $\mathrm{MOS}^{2}$ supplementation by about $57.14 \%$ $(\mathrm{P}<0.05)$ and $14.29 \%$, respectively than control rams. Individual skeletal muscle of Semimemberanosus (SM), Supraspinatus (SP) and Longissimus dorsi (LD) were increased in the case of the dietary supplementation with MOS. Consequently, it appears from the present study that the dietary of MOS improve carcass characteristics and meat quality. Moreover, MOS inclusion at $0.2 \%$ was the most effective, suggesting that MOS might be a potential type of food additive useful for the growing sheep in Upper Egypt conditions.

Keywords: Carcass characteristics, mannan oligosaccharides, Saidi rams.

Received on: 26/6/2014 Accepted for publication on: 21/7/2014

Referees: Prof. Soliman M. M. Mmousa Prof. Mohamed A. I. Salem 


\section{Introduction:}

Glycobiology is a relatively new field of study in the world of science. In the past decades, discoveries in the field of glycobiology have revealed the critical role of carbohydrates in the mechanisms of immunity (Munro, 2000; Axford, 2001). These discoveries will lead to the ability to use these functional carbohydrates, with a reduced use of antibiotics, in diets to improve performance and health of animals. There has of late been increasing pressure on the livestock industry to decrease the use of antibiotics due to the potential development of antibiotic resistance (Pettigrew, 2006; Stein and Kil, 2006). Among carbohydrates, mannan oligosaccharide (MOS), derived from the yeast cell wall of Saccharomyces cerevisiae, has been shown to improve animal performance and health through several mechanisms such as prevention of pathogens from binding to the gastrointestinal tract (GIT), alteration of GIT microbial populations, and enhancement of immune functions.

Growth and development of the animals is the basis for meat production whereas amount and site of fat in the carcass influences its quality (Karim et al., 2007 and Sen et al., 2004). On the other hand, we are insufficient literature that concerns the effects of dietary MOS supplementation, as a prebiotic additive, on carcass and meat composition in ruminants especially sheep.

The information on influence of prebiotics, such as MOS on carcass characteristics are very scarcity especially on rams. Therefore, the present study was aimed to assess the impact of MOS supplementation as growth pro- moting additive on carcass characteristics of rams under Upper Egypt conditions.

\section{Materials and Methods:}

The experiment was conducted at the Animal Experimental Farm, Animal Production Department, Faculty of Agriculture, Assiut University, Assiut, Egypt. The aim of this study was to determine body performance and carcass characteristics in rams supplemented with mannan oligosaccharide.

\section{Animals and management:}

Eighteen Saidi rams of about 24 $\mathrm{kg}$ body weight were used in this trial. Animals were assigned randomly to three treatment groups $(\mathrm{C}$, $\operatorname{MOS}^{1}$ and $\mathrm{MOS}^{2}$ ) with an average body weight, 24.00, 24.08 and 24.17 $\mathrm{kg}$, respectively. The control group (C) was fed on MOS free diet while $M^{1}$ and $\mathrm{MOS}^{2}$ treated groups received 2.0 and $4.0 \mathrm{~g} / \mathrm{kg}$ MOS $\left(\mathrm{MOS} ;\right.$ activeMOS $^{\circledR}$ ) supplementation in the diets ( $\mathrm{Li}$ et al., 2011). MOS are commercially available as Bio$\operatorname{Mos}{ }^{\circledR}$, which is a nutritional supplement manufactured by MOS ${ }^{\circledR}$ Matrix nutrition, LLC, USA was used in this experiment. Animals were fed roughage and concentrate diet ad libitum during the experimental period. The concentrate diet was consisted of $34 \%$ yellow corn, 38\% wheat bran, $25 \%$ decorticated cotton seeds $2 \%$ limestone and $1 \%$ sodium chloride. Chemical composition of the experimental trials and MOS are presented in Table (1). Animals were individually fed twice at 7:00 a.m and 3 p.m. daily. Water was offered three times daily at 8,12 a.m. and 5 p.m. 
Table 1. Chemical composition of the experimental trails (DM basis)

\begin{tabular}{|l|c|c|}
\hline \multicolumn{1}{|c|}{ Item } & Control & MOS \\
\hline Organic matter & 91.85 & 95 \\
\hline Crude Protein & 15.60 & 20 \\
\hline Ether extract & 4.18 & 1.5 \\
\hline Crude Fiber & 8.73 & 1.0 \\
\hline Nitrogen Free Extract & 61.54 & 72.5 \\
\hline Ash & 9.95 & 5.0 \\
\hline Polysaccharides & & \\
\hline B-Glucans & & 28 \\
\hline (MOS) & & 30 \\
\hline GE & 15.79 & 17.63 \\
\hline
\end{tabular}

Gross energy $(\mathrm{GE})(\mathrm{MJ} / \mathrm{kg})=(\%$ crude protein $\times 23.6+\%$ crude lipid $\times 39.5+\% \mathrm{NFE}$ $\times$ 17) ( Razeghi Mansour et al., 2011)

Slaughter and carcass characteristics:

The experimental period lasted for 6 months. At the end of the experimental period, 5 animals from the experimental groups were slaughtered. Animals were left fasting for 12 hours prior slaughtering and the fasted body weight (FBW) was recorded. Average final body weight was $44.17,48.50$ and $45.83 \mathrm{~kg}$ for control, $\mathrm{MOS}^{1}$ and $\mathrm{MOS}^{2}$ treated groups, respectively.

The feet were separated then the animals was skinned with much care. The weight of head, feet and pelt were recorded. The body cavity opened and the following organs were detached and weighed (liver, spleen, heart, lungs and trachea, digestive tract, kidneys, intestine, tail, fatting, gall bladder, reproductive system, heart fat, kidney and pelvic fat, gut fat intestine).

The weight of empty body was calculated as the difference between the weight of the fasted body and gut contents. Dressing percentages and percentage of hot carcass to fasted body weight were calculated. The carcass was split carefully into two sides and weighed. The left side was divided to retail cuts and the weight of tail, leg, sirloin, best neck, mid neck, fillet, neck, shoulder, brisket, flank and best rib were recorded. Samples of Longissimus Dorsi (LD), Semimembranosus (SM) and $\mathrm{Su}-$ praspinatus (SP) were taken for weight, length and circumference.

\section{Physiological volume}

The physiological volume of stomach components (Reticulorumen and Omaso-abomasum) and the intestinal segments (Small intestine, cecum and colon-rectum) were measured by the difference between the volume of each part when filled with its contents and its volume after empting the contents.

\section{Statistical analysis:}

Data were statistically analyzed using general linear model (G.L.M.) procedure of S.A.S. (2001). For carcass characteristics (slaughter), oneway classification was used as the following model,

$$
\mathrm{Yij}=\mu+\mathrm{Ti}+\mathrm{Eij}
$$

Where; Yij $=$ the observation. $\mu=$ General mean. $\mathrm{Ti}=$ Effect due to MOS treatment. Eij $=$ the errors related to individual observation.

\section{Results and Discussion:}

\section{Effect of Dietary MOS on car-} cass characteristics on:

\subsection{Non-edible parts of carcass:} The effect of $\mathrm{MOS}^{1}$ and $\mathrm{MOS}^{2}$ treatments on fasted body weight and 
non edible parts of rams are summarized in Table 2. MOS supplementation did not have a significant effect on fasted body weight, head, feet, pelt, full and empty rumen, full and empty intestine weight, physiological volume and gall bladder except lung plus trachea which decreased significantly $(\mathrm{P}<0.05)$ in $\mathrm{MOS}^{1}$ treated rams. However, fasted live body weight and most of such non edible parts tended to be heavier in MOS treated rams, while feet and gall bladder weights were lower in MOS treatments than controls. In this field, full rumen and physiological volume of rumen were lower by -2.37 and -
5.16 and higher by +2.71 and +6.05 in rams treated with $\operatorname{MOS}^{1}$ and $\mathrm{MOS}^{2}$ supplementation, respectively which compared with a control group.

Dietary $\operatorname{MOS}^{1}$ and $\mathrm{MOS}^{2}$ in rams' diet caused an increase in weights of fasted body weight, head, pelt, full and empty intestine and physiological volume of intestine segment by about $(9.93 \%, 5.52 \%)$, $(12.03 \%, 15.41 \%),(1.96 \%, 7.06 \%)$, $(2.67 \%, 17.33 \%),(1.42 \%, 0.71 \%)$ and $(3.77 \%, 32.07 \%)$ and decrease in weights of feet and gall bladder by about $(1.67 \%, 1.67 \%)$ and $(29 \%$, $27 \%$ ), respectively than in control ones.

Table 2. Effect of dietary MOS supplementation on fasted body Weight and nonedible Parts $(\mathrm{kg})$ of carcass of Saidi rams $(\mathrm{X} \pm \mathrm{SE})$.

\begin{tabular}{|l|c|cc|ccc|}
\hline \multirow{2}{*}{ Traits (kg) } & \multicolumn{3}{c|}{ Dietary treatments } & \multirow{2}{*}{ SE } & \multicolumn{3}{c|}{$\begin{array}{c}\text { \% Change } \\
\text { MOS1 }\end{array}$} & MOS2 \\
\cline { 2 - 4 } & Control & MOS $^{\mathbf{1}}$ & MOS $^{2}$ & & 4.93 & +5.52 \\
Fasted body weight & 45.30 & 49.80 & 47.80 & 5.46 & +9.93 & +15.41 \\
Head & 2.66 & 2.98 & 3.07 & 0.33 & +12.03 & +1.67 \\
Feet & 1.20 & 1.18 & 1.18 & 0.15 & -1.67 & -1.67 \\
Pelt & 5.10 & 5.20 & 5.46 & 0.89 & +1.96 & +7.06 \\
Lung and trachea (g) & $582^{\mathrm{ab}}$ & $539^{\mathrm{b}}$ & $621^{\mathrm{a}}$ & 56.5 & -7.38 & +6.70 \\
Rumen full & 5.90 & 5.76 & 6.06 & 1.14 & -2.37 & +2.71 \\
Rumen empty & 1.44 & 1.53 & 1.44 & 0.19 & +6.25 & 0.00 \\
Intestine full & 3.00 & 3.08 & 3.53 & 0.78 & +2.67 & +17.67 \\
Intestine empty & 1.41 & 1.43 & 1.42 & 0.27 & +1.42 & +0.71 \\
Physiological volume : & & & & & & \\
For rumen & 4.46 & 4.23 & 4.73 & 1.04 & -5.16 & +6.05 \\
For intestinal segment & 1.59 & 1.65 & 2.10 & 0.40 & +3.77 & +32.07 \\
Gall bladder (g) & 51 & 36 & 37 & 14.2 & -29.42 & -27.45 \\
\hline
\end{tabular}

$\operatorname{MOS}^{1}=$ Animal supplemented with $2 \mathrm{~g} / \mathrm{kg}$ diet. $\mathrm{MOS}^{2}=$ Animal supplemented with $4 \mathrm{gm} / \mathrm{kg}$ diet. $\mathrm{SE}=$ Standard error. ${ }^{\mathrm{a}, \mathrm{b}}$ Means in row with no common superscript differ significantly $(* \mathrm{P}<0.05)$

\subsection{Edible parts of carcass:}

The overall mean weights of liver, Heart, Kidney, tail fat, Kidney and pelvic fat, Gut fat, Intestine fat and total fat were not significantly affected by $\operatorname{MOS}^{1}$ and MOS$^{2}$ treatments. Moreover, the response of edible parts of carcass to $\mathrm{MOS}^{1}$ and $M^{2}{ }^{2}$ supplementation tended to be variable in experimental rams com- pared with control ones as shown in Table3. However, most of such parts tended to heavier for $\mathrm{MOS}^{2}$ than $\operatorname{MOS}^{1}$ treated rams when compared with a control group. While, there are a significant decrease in the weight of heart fat $(\mathrm{P}<0.05)$ for $\mathrm{MOS}^{2}$ treated rams compared to the control value. 
Table 3. Effect of dietary MOS supplementation on edible parts of carcass (g) of Saidi rams $(\mathrm{X} \pm \mathrm{SE})$.

\begin{tabular}{|c|c|c|c|c|c|c|}
\hline \multirow{2}{*}{ Traits (kg) } & \multicolumn{3}{|c|}{ Dietary treatments } & \multirow[t]{2}{*}{ SE } & \multicolumn{2}{|c|}{ \%Change } \\
\hline & Control & MOS $^{1}$ & MOS $^{2}$ & & $\operatorname{MOS}^{1}$ & $\operatorname{MOS}^{2}$ \\
\hline Liver & 697 & 718 & 838 & 178 & +3.01 & +20.23 \\
\hline Heart & 167 & 170 & 178 & 10.04 & +1.80 & +6.59 \\
\hline Kidney & 118 & 115 & 131 & 15 & -2.54 & +11.02 \\
\hline Tail fat (Kg) & 2.86 & 2.79 & 2.31 & 1.00 & -2.27 & -19.17 \\
\hline Heart fat & $68^{a}$ & $51^{\mathrm{a}}$ & $38^{\mathbf{b}}$ & 16.27 & -25 & -44 \\
\hline Kidney and pelvic fat & 183 & 149 & 113 & 63.92 & -18.58 & -38.25 \\
\hline Gut fat & 242 & 187 & 168 & 59.32 & -22.72 & -30.58 \\
\hline Intestine fat & 326 & 294 & 277 & 93.21 & -9.82 & -15.03 \\
\hline Total fat & 819 & 681 & 596 & 178 & -16.85 & -27.23 \\
\hline
\end{tabular}

$\mathrm{MOS}^{1}=$ Animal supplemented with $2 \mathrm{~g} / \mathrm{kg}$ diet. $\mathrm{MOS}^{2}=$ Animal supplemented with $4 \mathrm{~g} / \mathrm{kg}$ diet.

$\mathrm{SE}=$ Standard error ${ }^{\mathrm{a}, \mathrm{b}}$. Means in row with no common superscript differ significantly $(* \mathrm{P}<0.05)$

In the present study, $\operatorname{MOS}^{1}$ and $\operatorname{MOS}^{2}$ led to an increase in the weight of liver, heart and kidney by about $(3.01 \%$ and $20.23 \%),(1.8 \%$ and 6.59 $\%)$ and $\left(11.02 \%\right.$ in $\mathrm{MOS}^{2}$, respectively with insignificant differences. Although, the weight of tail fat, heart fat, kidney and pelvic fat, gut fat, intestine fat and total fat were decreased by $(2.27 \%$ and $19.17 \%)$, $(25 \%$ and $44 \%, \mathrm{P}<0.05)$, $(18.58 \%$ and $38.25 \%),(22.72 \%$ and $30.58 \%)$, $(9.82 \%$ and $15.03 \%)$ and $(16.83 \%$ and $27.23 \%$ ), respectively in $\operatorname{MOS}^{1}$ and $\operatorname{MOS}^{2}$ supplemented rams than control, however, the difference was not significant statistically.

Abd-Allah and Abdel-Raheem, (2012) reported that carcass of quails fed 3 g MOS supplemented diet had lower offal's weight and the relative liver and gizzard weights tended to be higher than other groups. In addition, Younger and older guinea fowl fed diets supplemented with MOS had reduced $(\mathrm{P}<0.05)$ liver weight and increased $(\mathrm{P}<0.05)$ spleen weight (Osoa et al., 2014).

The heavier of such parts of edible carcass in the present study (Table 4) may be related to dietary MOS increased concentrate intake. High concentrate intake increases en- ergy supply for protein synthesis/ growth and may increases serum glucose concentration, consequently, increase insulin concentration (Hadly, 1984). Insulin increased both number and size of cells (Gardner and Kaye, 1991). Murray and Slezacek (1980) illustrated that lambs fed a high plan of nutrition had greater weight of liver, kidney, pelts than similar fed a low plane of nutrition. In addition, thyroid hormones, which increase due to fed MOS (Sohail et al., 2010), accelerated cellular reactions in most organs and tissues of the body including the liver where these proteins are formed (Smith et al., 1983).

It is very interested to observe from the present study the reduction of edible parts for fat (tail fat, Heart fat, Kidney and pelvic fat, Gut fat, Intestine fat and total fat) in animals fed MOS (Table 3). Moreover, rams fed diet supplemented with $\mathrm{MOS}^{2}$ had numerically the lowest average fat percentage than other treatment$\operatorname{MOS}^{1}$ compared to the control group.

\section{Effect of dietary MOS supple- mentation on carcass components:}

The data presented in Table 4, display the effect of dietary MOS supplementation on carcass components. Hot carcass, right and left car- 
cass side weights for $\operatorname{MOS}^{1}$ and $\mathrm{MOS}^{2}$ - fed rams were heavier by $(15.01 \%$ and $4.66 \%),(14.79 \%$ and $3.96 \%)$ and $(14.20 \%$ and $5.35 \%$ ), while carcass length at les to pelvic and carcass depth at $7^{\text {th }}$ rib were lighter by $(0.58 \%$ and $4.52 \%)$ and $\left(1.38 \%\right.$ for $\left.\operatorname{MOS}^{1}\right)$, respectively than control rams but such differences not statistically different. The increase in hot carcass, left and right side may be related to the increase of fasted weight (Table 4). Highly significant $(\mathrm{P}<0.01)$ effect for fasted weight on hot carcass was reported in lambs by Cameron and Drury (1985). Similar findings were reported also by Dahmen et al., (1985) and Attalah (1988).

When weights of total carcass, right and left sides were related with fasted body weight, significant difference was found between $\operatorname{MOS}^{1}$ and both of $\mathrm{MSO}^{2}$ and control rams. Dressing, right and left side percentages were higher by $5.10 \%, 5.33 \%$ $(\mathrm{P}<0.05)$ and $4.11 \%$ in $\mathrm{MOS}^{1}$ rams group when compared with control ones. $\operatorname{MOS}^{2}$ showed an opposite direction The variations in the response to MOS treatment between right and left carcass side weights might be due to differences in the proportion of fasted and slow twitch fibers in muscle.

The increase in carcass weight of $\mathrm{MOS}^{\mathbf{1}}$ - fed rams might be due to the reduction of some non edible weight of carcass components than control rams (Table 2). Such improvement of carcass components might be due to the increase of both daily gain and body weight of MOStreated rams.

Table 4. Effect of dietary MOS supplementation on fasted body weight and carcass components $(\mathrm{kg})$ of Saidi rams $(X \pm S E)$.

\begin{tabular}{|c|c|c|c|c|c|c|}
\hline \multirow[b]{2}{*}{ Traits (kg) } & \multicolumn{3}{|c|}{ Dietary treatments } & \multirow[t]{2}{*}{ SE } & \multicolumn{2}{|c|}{ \%Change } \\
\hline & Contro ${ }^{1}$ & MOS $^{1}$ & MOS $^{2}$ & & $\operatorname{MOS}^{1}$ & $\operatorname{MOS}^{2}$ \\
\hline Fasted body weight & 45.30 & 49.80 & 47.80 & 5.46 & +9.93 & +5.52 \\
\hline Hot carcass & 19.32 & 22.22 & 20.22 & 2.26 & +15.01 & +4.66 \\
\hline Right side & 09.60 & 11.02 & 09.98 & 1.16 & +14.79 & +3.96 \\
\hline Left side & 09.72 & 11.10 & 10.24 & 1.09 & +14.20 & +5.35 \\
\hline Carcass length at les to pelvic $(\mathrm{cm})$ & 68.60 & 68.20 & 65.50 & 4.46 & -0.58 & -4.52 \\
\hline $\begin{array}{l}\text { Carcass depth at } 7^{\text {th }} \text { rib }(\mathrm{cm}) \\
\text { Carcass \% as of body weight, }\end{array}$ & 22.7 & 21.4 & 22.7 & 1.15 & -1.38 & 0000 \\
\hline Dressing \%, & 42.65 & 44.65 & 42.44 & 1.81 & +5.10 & -0.35 \\
\hline Right side $\%$, & $21.20^{\mathrm{b}}$ & $22.32^{\mathrm{a}}$ & $20.92^{b}$ & 0.82 & +5.33 & -0.38 \\
\hline Left side $\%$, & 21.45 & 22.33 & 21.52 & 1.05 & +4.11 & -0.55 \\
\hline
\end{tabular}

$\operatorname{MOS}^{1}=$ Animal supplemented with $2 \mathrm{~g} / \mathrm{kg}$ diet. MOS $^{2}=$ Animal supplemented with $4 \mathrm{~g} / \mathrm{kg}$ diet.

$\mathrm{SE}=$ Standard error ${ }^{\mathrm{a}, \mathrm{b}}$ Means in row with no common superscript differ significantly $(* \mathrm{P}<0.05)$

Gravert and Rosenhaha, (1965) showed that as the daily gain increased the percentage of muscle tissues increased. It was hypothesized that a decrease in intestinal pathogen challenge provided by MOS supplementation would resulted in improvement of nutrient utilization and allocation leading to benefit in lean muscle gain and dressing percentage ( Ferket, 2004).

\section{Effect of dietary MOS on compo- sition of left carcass side:}

Table (5) presents the effect of dietary MOS supplementation on composition of left carcass side of Saidi rams. The data revealed that, the $\operatorname{MOS}^{\mathbf{1}}$ and $\mathrm{MOS}^{2}$ fed rams had heavier leg, sirloin, best neck, mid 
neck, fillet, neck, shoulder and brisket cut weights than those of the control rams by $(7.26 \%$ and $7.59 \%)$, $(35.14 \%$ and $18.92 \%),(16.67 \%$ and $10 \%),(15.15 \%$ and $3.03 \%),(57.14 \%$ : $\mathrm{P}<0.05$, and $14.29 \%)$, $(4.17 \%$ for $\left.\operatorname{MOS}^{1}\right), \quad(12.36 \%$ and $9 \%)$ and $\left(18.68 \%\right.$ for $\left.\mathrm{MOS}^{1}\right)$, respectively. Moreover, flank and best rib cut weights had lighter by $(4.55 \%$ and $6.82 \%)$ and $(2.85 \%$ and $14.16 \%)$ for rams fed $\operatorname{MOS}^{1}$ and MOS $^{2}$ supplementation, respectively compared to the control values. In addition, leg and sirloin lengths increased by $\left(1.64 \%\right.$ and $8 . \%$ for $\left.\operatorname{MOS}^{1}\right)$ while circumference elevated by $(5.07 \%$ and $9.21 \%$ for $\mathrm{MOS}^{1}$ and $\mathrm{MOS}^{2}$ ) and $\left(9.6 \%\right.$ for $\left.\operatorname{MOS}^{1}\right)$ for leg and sirloin, respectively. However, such differences were not statistically significant. Meanwhile, a high priced cut (leg, sirloin and bested neck and fillet) was heavier by $29.05 \%$ and $12.7 \%$ of rams fed diet supplemented with $\operatorname{MOS}^{1}$ and $\operatorname{MOS}^{2}$ additives respectively compared to the controls. The highest part of high priced cuts was observed in fillet cut for $\operatorname{MOS}^{1}$ and $\operatorname{MOS}^{2}$ supplementation by about $57.14 \% \quad(\mathrm{P}<0.05)$ and $14.29 \%$, respectively than control rams (Table 5). It is cleared from the present results that the positive effect of MOS additives in rams fed diet ascribed to $\operatorname{MOS}^{1}$ which numerically the highest values of most carcass and a high priced carcass cut (Table 5). Dressing of best rib cuts showed that muscle, bone and fat percentages were lower by $(6.25 \%$ and $9.77 \%),(11.24 \%$ and $3.37 \%)$ and (32.46\%: $\mathrm{P}<0.05$ for $\mathrm{MOS}^{2}$ ) for rams fed diet supplemented with $\operatorname{MOS}^{1}$ and $\operatorname{MOS}^{2}$, respectively compared with a control ones. In addition, muscle/bone ratio and muscle/fat ratio had higher by $(5.92 \% 33.93 \%: \mathrm{P}<0.05)$ and lower by $(15.63 \%$ and $6.62 \%)$ for $\operatorname{MOS}^{1}$ and $\mathrm{MOS}^{2}$ supplementation, respectively compared to the control values (Table5). This may attributed to the higher lean and lower fat contents in rams fed MOS (Table $3 \& 5$ ). The increase in carcass components of MOS- fed rams might be due to the increase of both daily gain and body weight of MOS- treated rams Gravert and Rosenhaha, (1965) showed that as the daily gain increased the percentage of muscle tissues increased.

\section{Effect of dietary MOS on indi- vidual muscle weight:}

Mannan oligosaccharide effect of individual muscle weights are shown in Table (6). All Individual skeletal muscle measurements (weight, length and circumference) were higher in rams fed MOS than control rams with no significant differences. Weight, length and circumference of semimembranosus (SM), supraspindus (SP) and longissimas dorsi (LP) were increased by $(6.98 \%$ and $3.10 \%),(12.42 \%$ and 16.77$)$, $(22.22 \%$ and $24.24 \%)$ for weight, $(14.67 \%, \mathrm{P}<0.05$ and $9.33 \%),(1.37 \%$ and $4.11 \%),(7.29 \%$ and $2.08 \%)$ for length and $(4.31 \%$ and $6.90 \%)$, $(8.66 \%, \mathrm{P}<0.05$ and $5.51 \%),(21.21 \%$ and $21.21 \%$ ) for circumference, while LD -shape ration have decreased by $12 \%$ and 9.92. of $\operatorname{MOS}^{1}$ and $\mathrm{MOS}^{2}$ supplementation, respectively compared to the controls. When weight of individual muscle was related to left side weight, SM muscle insignificantly decreased by $6.77 \%$ and $2.26 \%$, while LD muscle increased by $5.88 \%$ and $18.62 \% \quad(\mathrm{P}<0.05)$ for $M{ }^{1}$ and $\operatorname{MOS}^{2}$ doses in the diets, respectively, relative to control rams. 
Table 5. Effect of dietary MOS supplementation on left carcass composition side (kg) of Saidi rams $(\mathrm{X} \pm \mathrm{SE})$.

\begin{tabular}{|c|c|c|c|c|c|c|}
\hline \multirow{2}{*}{ Traits (kg) } & \multicolumn{3}{|c|}{ Dietary treatments } & \multirow[t]{2}{*}{ SE } & \multicolumn{2}{|c|}{ \% Change } \\
\hline & Contro ${ }^{1}$ & $\operatorname{MOS}^{1}$ & $\operatorname{MOS}^{2}$ & & $\operatorname{MOS}^{1}$ & $\operatorname{MOS}^{2}$ \\
\hline $\begin{array}{l}\text { Left carcass side } \\
\text { Leg measurements : }\end{array}$ & 09.72 & 11.10 & 10.24 & 1.09 & +14.20 & +5.35 \\
\hline Leg & 3.03 & 3.25 & 3.26 & 0.40 & +7.26 & +7.59 \\
\hline Leg length $(\mathrm{cm})$ & 42.70 & 43.40 & 41.20 & 3.01 & +1.64 & -3.51 \\
\hline $\begin{array}{l}\text { Leg circum. at } 50 \% \text { of length }(\mathrm{cm}) \\
\text { Sir loin measurements: }\end{array}$ & 21.70 & 22.80 & 23.70 & 1.56 & +5.07 & +9.21 \\
\hline$\overline{\text { Sir loin }}$ & 0.74 & 1.00 & 0.88 & 0.20 & +35.14 & +18.92 \\
\hline Sir loin length $(\mathrm{cm})$ & 24.20 & 26.40 & 24.40 & 2.90 & +8.26 & +0.83 \\
\hline Sir loin circum. at $50 \%$ of length $(\mathrm{cm})$ & 19.80 & 21.70 & 18.70 & 0.33 & +9.6 & -5.56 \\
\hline Best neck ( 1-6) ribs & 0.60 & 0.70 & 0.66 & 0.07 & +16.67 & +10 \\
\hline Mid neck (7-12) ribs & 0.66 & 0.76 & 0.68 & 0.15 & +15.15 & +3.03 \\
\hline Fillet & $0.14^{\mathrm{b}}$ & $0.22^{\mathrm{a}}$ & $0.16^{\mathrm{ab}}$ & 0.04 & +57.14 & +14.29 \\
\hline Neck & 0.96 & 1.00 & 0.94 & 0.14 & +4.17 & -2.08 \\
\hline Shoulder & 1.78 & 2.00 & 1.94 & 0.25 & +12.36 & +9.00 \\
\hline Brisket & 0.91 & 1.08 & 0.90 & 0.30 & +18.68 & -3.30 \\
\hline Flank & 0.44 & 0.42 & 0.41 & 0.18 & -4.55 & -6.82 \\
\hline Best rib (g) ( 9-11 ribs) & 459 & 446 & 394 & 129 & -2.83 & -14.16 \\
\hline Dressing of best rib weight, & & & & & & \\
\hline Best rib muscle (g) & 256 & 240 & 231 & 66.32 & -6.25 & -9.77 \\
\hline Best rib bone $(\mathrm{g})$ & 89 & 79 & 86 & 16.85 & -11.24 & -3.37 \\
\hline Best rib fat (g) & $114^{\mathrm{a}}$ & $127^{\mathrm{a}}$ & $77^{\mathrm{b}}$ & 68.99 & +11.40 & -32.46 \\
\hline Muscle / bone ratio & 2.87 & 3.04 & 2.68 & 0.33 & +5.92 & -6.62 \\
\hline Muscle/ fat ratio & $2.24^{\mathrm{b}}$ & $1.89^{\mathrm{b}}$ & $3^{\mathrm{a}}$ & 0.54 & -15.63 & +33.93 \\
\hline
\end{tabular}

$\mathrm{MOS}^{1}=$ Animal supplemented with $2 \mathrm{~g} / \mathrm{kg}$ diet. $\mathrm{MOS}^{2}=$ Animal supplemented with $4 \mathrm{~g} / \mathrm{kg}$ diet.

$\mathrm{SE}=$ Standard error. ${ }^{\mathrm{a}, \mathrm{b}}$ Means in row with no common superscript differ significantly $(* \mathrm{P}<0.05)$.

The difference in response between muscles may be due to differences in the proportion of fast and slow twitch fibers in the muscle or may be attributed to differences in the proportion of muscle/bone ratio and muscle/ fat ratio (Table 8). The different responses between three muscles for muscle weight may be due to fiber type of muscle. Yang and Mc Elligott (1989) noted from histochemical observations that the anabolic affect may be specific to certain fiber types. Muscles are composed of various ratio of type I (slow- contracting, oxidative) and type II (fastcontracting, mixed glucolytic /oxidative) fibers. In addition, the increase of muscle weight was due to hypertrophic model of MOS induced muscle growth in addition to the increase in protein content (Newbold et al., 1997).

There is no available data on the effects of dietary MOS on composition of skeletal muscles (SM, SP and LD), but there are indirect effect only through the effect of thyroid hormones on composition of muscles., whereas dietary supplementations of $0.5 \%$ MOS increased $(\mathrm{P}<0.05)$ thyroxine $\left(\mathrm{T}_{4}\right)$ concentration in broilers as reported by (Sohail et al., 2010). Thyroid hormones are associated with protein synthesis and degradation. Cullen and Oace (1976) stated that "thyroid hormones have a biphasic effect on protein synthesis, at normal physiological levels as it increase the rate of protein synthesis 
but higher levels lead to the breakdown of protein". Diamant et al., (1972) showed that the thyroid hormone increased enzyme activities associated with both fatty acid synthesis and degradation. It could be concluded from the previous results that dietary of MOS improve carcass characteristics and meat quality. Moreover, MOS inclusion at $0.2 \%$ was the more effective, suggesting that MOS might be a potential type of food additive useful for the growing sheep in Upper Egypt conditions.

Table 6. Effect of dietary MOS supplementation on individual muscle weight of carcass components of Saidi rams $(X \pm S E)$.

\begin{tabular}{|c|c|c|c|c|c|c|}
\hline & \multicolumn{3}{|c|}{ Dietary treatments } & \multirow{2}{*}{ SE } & \multicolumn{2}{|c|}{ \%Change } \\
\hline & Contro $^{1}$ & MOS $^{1}$ & MOS $^{2}$ & & MOS $^{1}$ & $\operatorname{MOS}^{2}$ \\
\hline $\begin{array}{l}\text { Left side weight, }(\mathrm{Kg}) \\
\text { Semimemberanosus (SM) }\end{array}$ & 9.72 & 11.10 & 10.24 & 1.10 & +14.20 & +5.35 \\
\hline SM weight, $(\mathrm{g})$ & 129 & 138 & 133 & 20.16 & +6.98 & +3.10 \\
\hline SM length, $(\mathrm{cm})$ & $15.00^{\mathrm{b}}$ & $17.20^{\mathrm{a}}$ & $16.40^{\mathrm{ab}}$ & 1.47 & +14.67 & +9.33 \\
\hline SM cricum, $(\mathrm{cm})$ & 11.60 & 12.10 & 12.40 & 0.94 & +4.31 & +6.90 \\
\hline Supraspindus (SP) & & & & & & \\
\hline SP weight, (g) & 161 & 181 & 188 & 27.34 & +12.42 & +16.77 \\
\hline SP length, (cm ) & 21.90 & 22.20 & 22.80 & 1.09 & +1.37 & +4.11 \\
\hline SP cricum, $(\mathrm{cm})$ & $12.70^{\mathrm{b}}$ & $13.80^{\mathrm{a}}$ & $13.40^{\mathrm{ab}}$ & 0.69 & +8.66 & +5.51 \\
\hline Longissimus Dorsi (LD) & & & & & & \\
\hline LD weight, (g) & 99 & 121 & 123 & 15.73 & +22.22 & +24.24 \\
\hline LD length, (cm ) & 9.60 & 8.90 & 9.80 & 2.14 & +7.29 & +2.08 \\
\hline LD cricum, $(\mathrm{cm})$ & 13.20 & 16 & 16 & 0.70 & +21.21 & +21.21 \\
\hline LD -shape ( ratio ) & 1.31 & 1.15 & 1.18 & 0.19 & -12.24 & -9.92 \\
\hline Carcass $\%$ as of left side weight, & & & & & & \\
\hline SM \% & 1.33 & 1.24 & 1.30 & 0.13 & -6.77 & -2.26 \\
\hline SP\% & 1.66 & 1.62 & 1.83 & 0.14 & -2.41 & +10.24 \\
\hline LD\% & $1.02^{\mathrm{b}}$ & $1.08^{\mathrm{ab}}$ & $1.21^{\mathrm{a}}$ & 0.12 & +5.88 & +18.62 \\
\hline
\end{tabular}

$\operatorname{MOS}^{1}=$ Animal supplemented with $2 \mathrm{~g} / \mathrm{kg}$ diet. $\mathrm{MOS}^{2}=$ Animal supplemented with $4 \mathrm{~g} / \mathrm{kg}$ diet.

$\mathrm{SE}=$ Standard error ${ }^{\mathrm{a}, \mathrm{b}}$ Means in row with no common superscript differ significantly $(* \mathrm{P}<0.05)$.

\section{References:}

Abd-Allah, SH.M.S and SH. M. Abdel-Raheem. 2012. Effect of dietary mannan oligosaccharides supplementation level on the carcass characteristics, meat quality and intestinal microbial ecology of Japanese Quail (Coturnix Japonica). Assiut Vet. Med.J.Vol.58 No.135: 41-49.

Attalah,G.Y. 1988. Studies on fatting cross breed lambs. M.Sc. Thesis, Fac. of Agric.,Al-Azhar Univ.

Axford, J. 2001. The impact of glycobiology on medicine. Trends Immunol. 22:237-239.

Cameron, N. D. and D. J. Drury.1985. Comparison of terminal sire breeds for growth and carcass traits in crossbred lambs. Anim. Prod., 40:315-322.

Cullen, R. and S. Oace. 1976. Minerals elements. In: D. A.Wenk and S. P. Dewan (Eds), Nutrition the challenge of being well nourished, pp. 215-246, Reston publishing Company. Reston, Virginia.

Dahmen,J. J., J. A. Jacolbs and E.J. Morrison. 1985. Suffolk versus lincoln rams: The influence of sire and breed cross on carcass traits on heavy market lambs. J. Anim. Sci., 61:98-105.

Diamant, S., E. Gorin and E.Shafrir. 1972. Enzyme activities related 
to fatty-acid synthesis in liver and adipose tissue of rats treated with triiodothyronine. Eur. J. Biochem. 26:553-559.

Ferket, P.R.2004. Alternatives to antibiotics in poultry production: responses, practical experience and recommendations. Nutritional biotechnology in the feed and food industries: Proceedings of Alltech's 20 ${ }^{\text {th }}$ Annual Symposium, Kentucky, USA, pp:5667.

Gardner, H. G. and P.L.Kaye.1991. Insuline increase cell numbers and morphological development in mouse preimplantation embryos in vitro Rep., Fer and Dev., 3:79-91.

Gravert, H. O. and E. C. Rosenhahn. 1965. Which fattening and beef characters in cattle are economically important. Zuchtungskunde. 37:244-250.

Hadley, M. E.1984. Pancreatic hormones and metabolic regulation, thyroid hormones and hormones of males reproductive physiology. In: Endocrinology, pp. 235-263, 292-317, 402-440, Prentice-Hall, INC. ,Englewood Cliffs, New Jersey.

Karim, S. A., Kuldeep Porwal, Kumar Suresh and V.K. Singh.2007. Carcass traits of Kheri lambs maintained on different system of feeding management. Meat Sci., 76 (2007), pp. 395-401.

Li,G.H.,B.M.Ling,M.R.Qu,J.M.You and X.Z.Song.2011. Effect of several oligosaccharides on ruminal fermentation in sheep. an in vitro experiment. Revue.Med.Vet.162, 4,192-197.
Munro, S. 2000. Essentials of glycobiology. Trends Cell Biol. 10:552-553. Murtaugh,

Murray, D.M. and O.Slezacek. 1980. Growth rate effects of sheep. J. Agric. Sci. (Camb.), 95: 241250.

Newbold, C. J., El-Hassan, S.M., Wang, J., Ortega, M.E. and Wallace, R.J. 1997. Influence of foliage African multipurpose trees on activity of rumen protozoa and bacteria. British Journal of Nutrition, 78: 237-249.

Osoa, A. O., G.A. Williamsa,A.V. Jegedea, R.A. Sobayoa, O.M.O. Idowua, A.O. Fafiolua, O.M. Sogunleb, O.S. Akinolab, O.O. Adeleyeb, I.A.R. Olorunsolac, I. M. Ogunadea, S.O. Oshoa, F.O. Obadired and A.M. Bamgbosea. 2014. Effect of combination of whole millet feeding and mannan oligossaccharides supplementation on growth performance, serum biochemistry and relative organ weights of growing guinea fowl (Numidia meleagris). Livestock Science. Volume 159, January 2014, Pages 46-52.

Pettigrew, J. E. 2006. Reduced use of antibiotic growth promoters in diets promoters in diets fed to weanling pigs: dietary tools, part 2. Anim. Biotechnol. 17:217231.

Razeghi Mansour.M., R. Akrami, S. H. Ghobadi, K. Amani Denji, N. Ezatrahimi and A. Gharaei 2011. Effect of dietary mannan oligosaccharide (MOS) on growth performance, survival, body composition, and some hematological parameters in giant sturgeon juvenile (Huso huso Linnaeus, 1754). Fish 
Physiology and Biochemistry (C) Springer Science + Business Media B. V. 2011. 10.1007/s 10695-011-9570-4

SAS Institute. 2001. SAS User's Guide: Statistics. Version8. SAS Institute Inc, Cary. North Carolina.

Sen, A. R., A. Santra and S.A. Karim. 2004. Carcass yield, composition and meat quality attributes of sheep and goat under semiarid conditions. Meat Sci., 66 (2004), pp. 757-76.

Smith, E. L., R. L. Hill, I. R. Lehman, R. J. Lefkowitz, P. H. Handler and A. White. 1983. The thyroid. In: Principles of Biochemistry: Mammalian Biochemistry ( $7^{\text {th }}$ Ed.). PP 416-440. mCgRAW Hill Book Co., New York.
Sohail M.U., A. Ijaz , M.S .Yousaf , K. Ashraf, H .Zaneb, Aleem, M. and H. Rehman. 2010. Alleviation of cyclic heat stress in broilers by dietary supplementation of mannan-oligosaccharide and Lactobacillus-based probiotic: dynamics of cortisol, thyroid hormones, cholesterol, Creactive protein, and hum oral immunity. Poult Sci. 2010 Sep; 89 (9): 1934-8. doi: 10.3382/ps. 2010-00751.

Stein, H. H., and D. Y. Kil. 2006. Reduced use of antibiotic growth sugars. Chem. Rev. 96:683-720.

Yang,Y. R. and M. A. McElligott. 1989. Multiple actions of $\beta-$ adrenergic agonists on skeletal muscle and adipose tissue. Biochem. J., 261:1. 
صفات الأبيحة فى ذكور الاغنام الصعيدى المغذاة على عليقة مضاف اليها سكر المنان محمد وائل حسن دغش، محمد نصرت محمود، فاروق محمد علام و سيف اليزل فتحى عباس قسم الانتاج الحيو اني - كلية الزر اعة - جامعة أسيوط

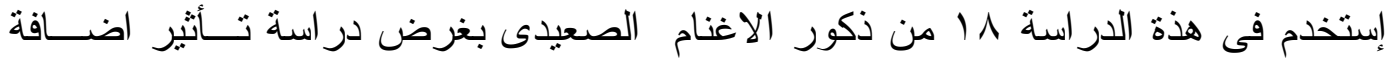

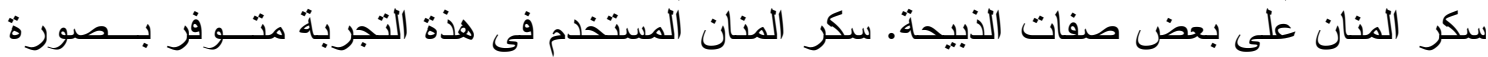

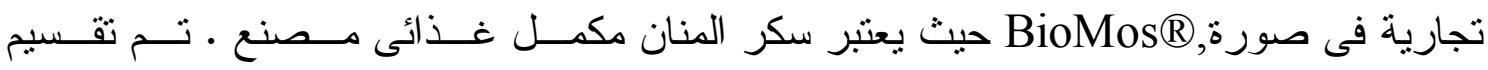

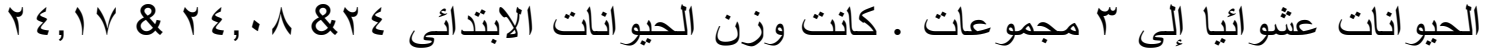

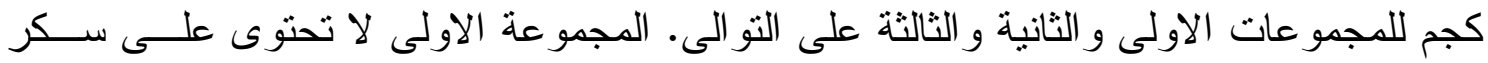

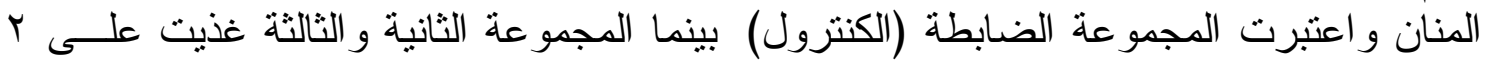

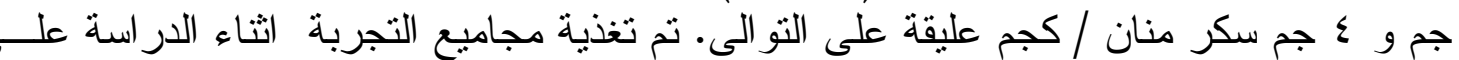

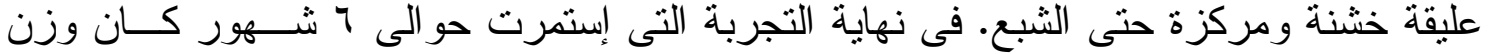

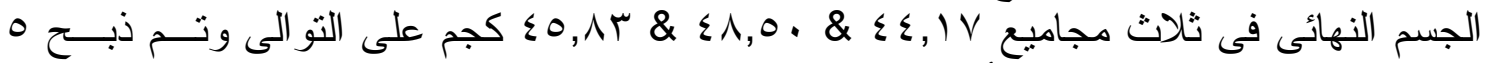
حيو انات من كل مجموعة. وقد أظهرت النتائج زيادة فى وزن الذبيحة ، نسبة التصافي ، نـسبة أنساة

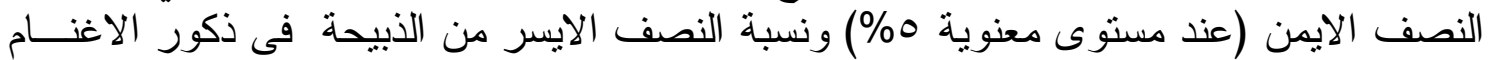

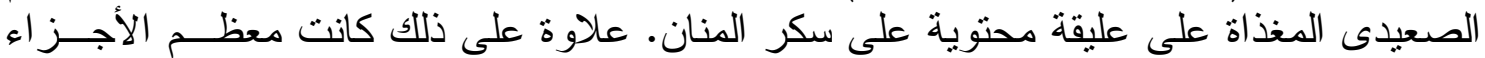

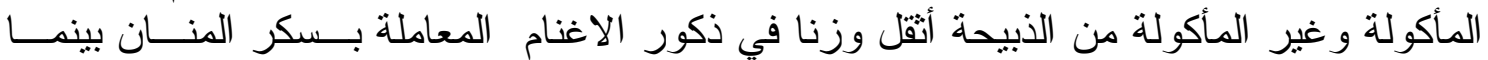

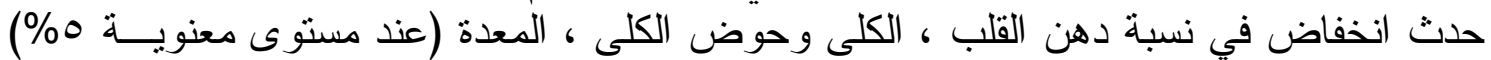

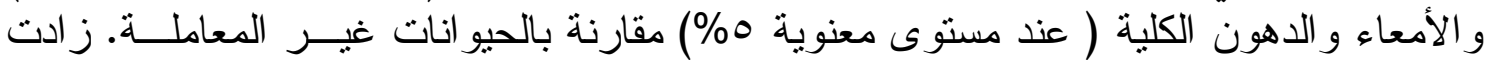

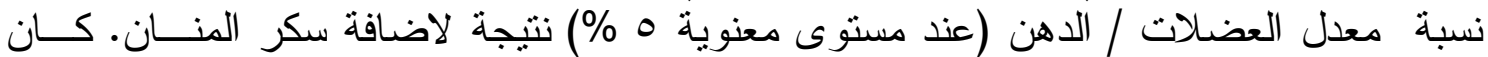

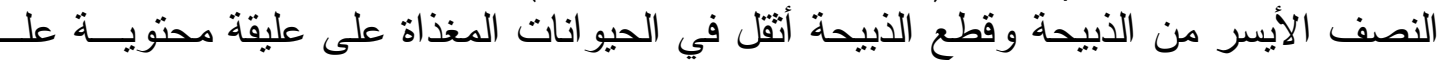
سكر المنان مقارنة بالمجموعة الضابطة. علاوة على ذلك كانت القطعيات مرتفعة الـسعر مــن

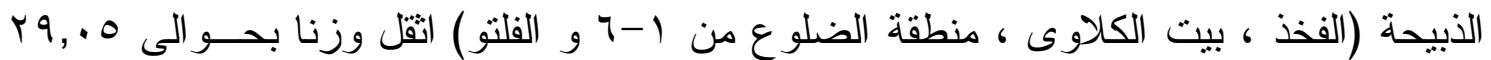

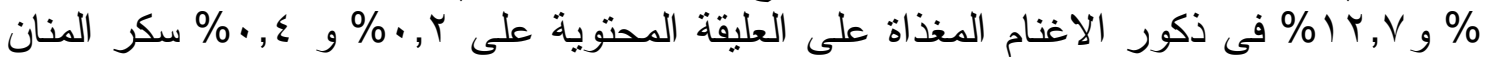

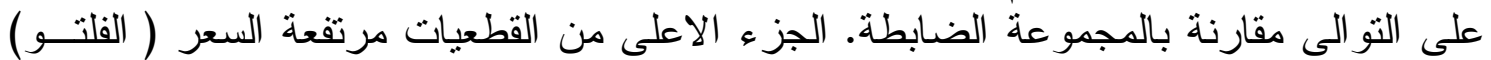

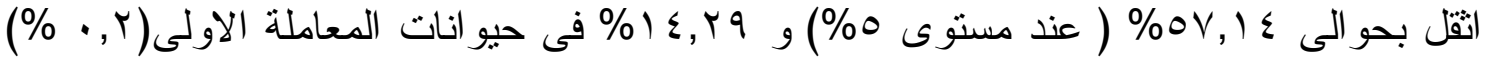

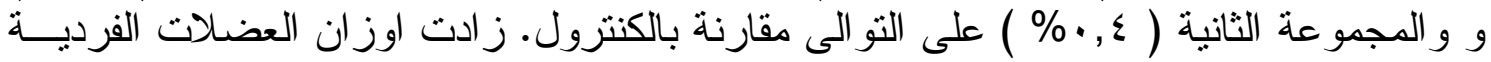

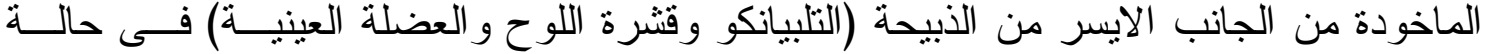

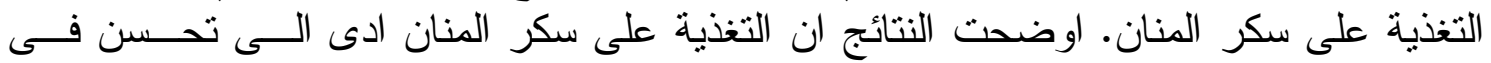

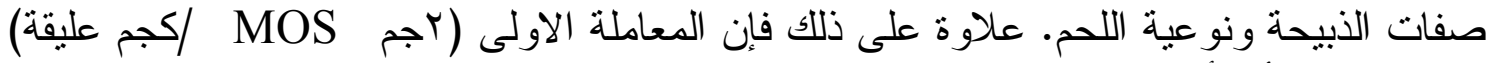

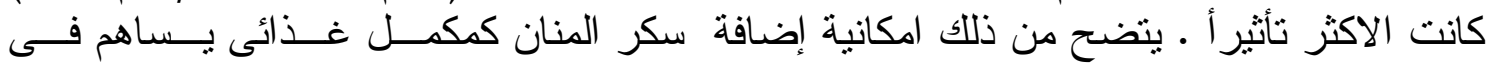

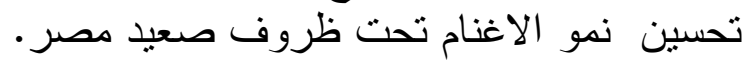

